\title{
Pengujian Implementasi Sistem Pengelolaan Keuangan Masjid Berbasis Web Dan Android
}

\author{
Fachruddin $^{1}$, M. Riza Pahlevi ${ }^{2}$, Muhammad Ismail ${ }^{3}$, Errissya Rasywir ${ }^{4}$ \\ ${ }^{1,2,3,4}$ Universitas Dinamika Bangsa Jambi \\ e-mail: ${ }^{1}$ fachruddin.stikom@gmail.com, ${ }^{2}$ rizapahlevikuliah@gmail.com, ${ }^{3}$ maelkhanz@gmail.com, \\ ${ }^{4}$ errissya.rasywir@gmail.com,
}

\begin{abstract}
Manual financial management is one of the causes of data loss and report files. Meanwhile, financial reports are data that must be accounted for. As with our observations, the Darusalam Mosque (Pakuan Baru Village in Jambi City) quite often experiences these classic problems. With the use of Android-based application technology, it is hoped that the mosque's financial data will be more organized, neatly archived and transparent. The digital financial management or accounting system allows flexibility in accessing mosque financial reports. Therefore it is necessary to build a Mosque Financial Management System Based on the Android Platform. The Android-based financial management application will later be launched on Google Playstore, so that all parties who need this system can download this application for free. The application of applications with a whole series of good software engineering must be carried out in accordance with applicable business processes and do not change the flow of data and reports that have been running for years. The application of the Website-based application and the Android Platform that we did, was able to produce automatic and computerized mosque financial management and was considered very good in user testing.
\end{abstract}

Keywords: Software Engineering, UML, Android, Software, Testing.

Abstrak - Pengelolaan keuangan secara manual merupakan salah satu penyebab hilangnya data dan file laporan. Sedangkan laporan keuangan merupakan data yang harus dipertanggungjawabkan. Seperti pengamatan kami, Masjid Darusalam (Desa Pakuan Baru di Kota Jambi) cukup sering mengalami masalah klasik tersebut. Dengan penggunaan teknologi aplikasi berbasis android diharapkan data keuangan masjid lebih tertata, diarsipkan dengan rapi dan transparan. Sistem pengelolaan atau akuntansi keuangan digital memungkinkan adanya fleksibilitas dalam mengakses laporan keuangan masjid. Oleh karena itu perlu dibangun Sistem Manajemen Keuangan Masjid Berbasis Platform Android. Aplikasi pengelolaan keuangan berbasis android ini nantinya akan diluncurkan di google playstore, sehingga semua pihak yang membutuhkan sistem ini dapat mendownload aplikasi ini secara gratis. Penerapan aplikasi dengan keseluruhan rangkaian rekayasa perangkat lunak yang baik harus dilakukan sesuai dengan proses bisnis yang berlaku dan tidak mengubah arus data dan laporan yang telah berjalan bertahun-tahun. Aplikasi aplikasi berbasis Website dan Platform Android yang kami buat mampu menghasilkan pengelolaan keuangan masjid secara otomatis dan terkomputerisasi serta dinilai sangat baik dalam pengujian pengguna.

Kata Kunci: Rekayasa Perangkat Lunak, UML, Android, Perangkat Lunak, Pengujian.

\section{PENDAHULUAN}

Pengelolaan keuangan yang dilakukan secara manual menjadi salah satu penyebab kehilangan data dan berkas laporan. Sedangkan, laporan keuangan adalah data yang harus dipertanggungjawabkan. Hasil observasi kami di Masjid Darusalam (Kelurahan Pakuan Baru di Kota Jambi) cukup sering mengalami masalah klasik tersebut.

Berdasarkan hal tersebut, penelitian ini menawarkan aplikasi pembukuan atau pengelolaan keuangan secara digital. Dengan pemanfaatan teknologi aplikasi berbasis android diharapkan data keuangan masjid menjadi lebih tertata, terarsip dengan rapi serta transparan. Sistem pengelolaan atau pembukuan keuangan secara digital membuat keleluasaan dalam mengakses laporan keuangan masjid (Diani, 2014). Hal ini dapat menghindari prasangka negatif yang tak jarang timbul dari masyarakat. Sistem ini juga diharapkan sangat membantu pengurus agar transparan dalam menyampaikan laporan keuangan. Sebab, melalui aplikasi ini, tidak hanya pengurus, semua laporan keuangan juga bisa diakses oleh pihak luar. Pencatatan keuangan penting (Alamsyah, Rahayu, \& Muslih, 2017) untuk semua instansi, termasuk masjid, supaya bisa memberikan pertanggungjawaban pengelolaan keuangan kepada masyarakat (Rusmayanti, 2015).

Namun terdapat hambatan lain, yakni tenaga pengelola keuangan berbasis aplikasi adalah generasi yang tidak terlalu familiar dengan teknologi. Hal ini menjadi kendala untuk pemanfaatan aplikasi. Oleh karena itu perlu dibangun Sistem Pengelolaan Keuangan Masjid Berbasis Platform Android yang nantinya akan di 
launching di google playstore, sehingga semua pihak yang membutuhkan sistem ini dapat mendownload aplikasi ini secara gratis. Namun, sebelum tahap release aplikasi, aplikasi diharapkan telah melewati analisis pengujian.

Penelitian ini membahas bagaimana analisis dan penerapan implementasi Sistem Pengelolaan Keuangan Masjid Berbasis Platform Android. Aplikasi ini bertujuan untuk memudahkan pengelola keuangan masjid menyampaikan laporan keuangan secara transparan dan akuntabel serta membantu pengurus menyampaikan laporan keuangan secara terbuka dan bertanggung jawab kepada jamaah masjid. Sedangkan hasil penelitian ini diharapkan adalah Sistem Pengelolaan Keuangan Masjid Berbasis Platform Android.

\section{Transparansi Pengelolaan Keuangan}

Sering didapati laporan keuangan oleh pengurus Masjid Darusalam (Kelurahan Pakuan Baru di Kota Jambi) mengenai kehilangan data dan berkas pengeluaran. Pengelolaan keuangan yang dilakukan secara manual menjadi salah satu penyebabnya (Alamsyah et al., 2017; Nugraha \& Astuti, 2013). Terlebih laporan keuangan adalah data yang harus dipertanggungjawabkan kepada jamaah masjid. Berdasarkan hal tersebut, penelitian ini menawarkan aplikasi pembukuan atau pengelolaan keuangan secara digital (Juwita, 2013). Dengan pemanfaatan teknologi aplikasi berbasis android diharapkan data keuangan masjid menjadi lebih tertata, terarsip dengan rapi serta transparan. Sistem pengelolaan atau pembukuan keuangan secara digital membuat keleluasaan dalam mengakses laporan keuangan masjid (Rusmayanti, 2015). Hal ini dapat menghindari prasangka negatif yang tak jarang timbul dari masyarakat. Sistem ini juga diharapkan sangat membantu pengurus agar transparan dalam menyampaikan laporan keuangan.

Namun terdapat hambatan lain, yakni tenaga pengelola keuangan berbasis aplikasi adalah generasi yang tidak terlalu familiar dengan teknologi. Hal ini menjadi kendala untuk pemanfaatan aplikasi. Oleh karena itu perlu dibangun Sistem Pengelolaan Keuangan Masjid Berbasis Platform Android.

\section{Aplikasi Perangkat Lunak}

Pada pengembangan perangkat lunak Android biasanya dikembangkan dalam bahasa pemrograman Java dengan menggunakan Software Development Kit Android. Rancangan antarmuka Android umumnya digerakan dengan sentuhan misalnya menggeser, mengetuk, dan mencubit untuk memanipulasi objek di layar, serta papan keyboard virtual. Android merupakan sistem operasi dengan open source dan dirilis Google di bawah Lisensi Apache. Kode dengan open source dan lisensi perizinan pada Android memungkinkan perangkat lunak untuk dimodifikasi secara bebas dan didistribusikan oleh para developer software atau pengembang aplikasi (Popli, 2014).

Selain itu, Android memiliki komunitas pengembang aplikasi yang luas untuk fungsionalitas perangkat. Saat ini terdapat 50 miliar aplikasi telah diunduh dari Google Playstore. Sebuah survei menyebutkan bahwa Android adalah platform paling populer bagi para pengembang, digunakan oleh $71 \%$ pengembang aplikasi bergerak (Enck, Octeau, \& Mcdaniel, 2011).

\section{Unified Modelling Languange}

Pada penelitian ini dibangun Sistem Pengelolaan Keuangan Masjid Berbasis Platform Android menggunakan pemodelan Unified Modelling Languange (Dennis \& Haley, 2010).

Pemodelan yang dilakukan bertujuan untuk memvisualisasikan dan merepresentasikan relasi file kelas pada sistem, mendeskripsikan interaksi kegiatan user dengan sistem serta memvisualisasikan alur kegiatan proses kegiatan dalam sistem (Fachruddin \& Pratama, 2017).

\section{METODOLOGI PENELITIAN}

Bagian ini menunjukan langkah kegiatan yang kami lakukan dalam Pengujian Implementasi Sistem Pengelolaan Keuangan Masjid Berbasis Web Dan Android. Berikut ini adalah metodologi penelitian yang kami jalani:

\section{Identifikasi Proses Bisnis Pengelolaan Keuangan Masjid.}

Pada bagian ini kami memetakan proses bisnis pengelolaan keuangan masjid. Terdapat beberapa alur proses paling penting seperti menyampaikan laporan keuangan secara transparan dan akuntabel kepada jamaah masjid serta membantu pengurus menyampaikan laporan keuangan secara terbuka dan bertanggung jawab kepada jamaah masjid. Sebab, melalui aplikasi ini, tidak hanya pengurus, semua laporan keuangan juga bisa diakses oleh pihak luar.

Selain itu, proses pencatatan keuangan penting untuk semua instansi, termasuk masjid, supaya bisa memberikan pertanggungjawaban pengelolaan keuangan kepada masyarakat. Sehingga, kami meraancang database aplikasi sehingga data-data yang seharusnya terintegrasi dapat direlasikan dengan baik tanpa adanya redudansi data.

\section{Analisis Rancangan Solusi Sistem yang Diajukan.}

Melakukan analisis solusi permasalahan pengelolaan keuangan masjid untuk sistem pengelolaan keuangan masjid berbasis platform Android.

Proses memvisualisasikan dan merepresentasikan relasi file kelas pada sistem penelitian ini 
menggunakan diagram kelas, proses mendeskripsikan interaksi kegiatan user dengan pada sistem penelitian ini menggunakan diagram usecase serta memvisualisasikan alur kegiatan proses kegiatan dalam sistem menggunakan diagram aktivitas

\section{Peracangan Sistem Pengelolaan Keuangan Masjid.}

Pada tahapan ini dibuat perancangan pemodelan sistem pengelolaan keuangan masjid berbasis open source dengan platform android.

Faktor tersebut dikarenakan sistem operasinya merupakan yang paling banyak digunakan di dunia, mengalahkan Symbian. Android juga dipilih berbagai perusahaan teknologi yang menginginkan sistem operasi dengan cost rendah, costumable dan ringan untuk perangkat berteknologi tinggi. Sifat Android yang terbuka juga telah mendorong munculnya sejumlah besar komunitas pengembang aplikasi untuk menggunakan open source code sebagai pembuatan aplikasi yang memudahkan penambahan fitur-fitur baru bagi pengguna Android.

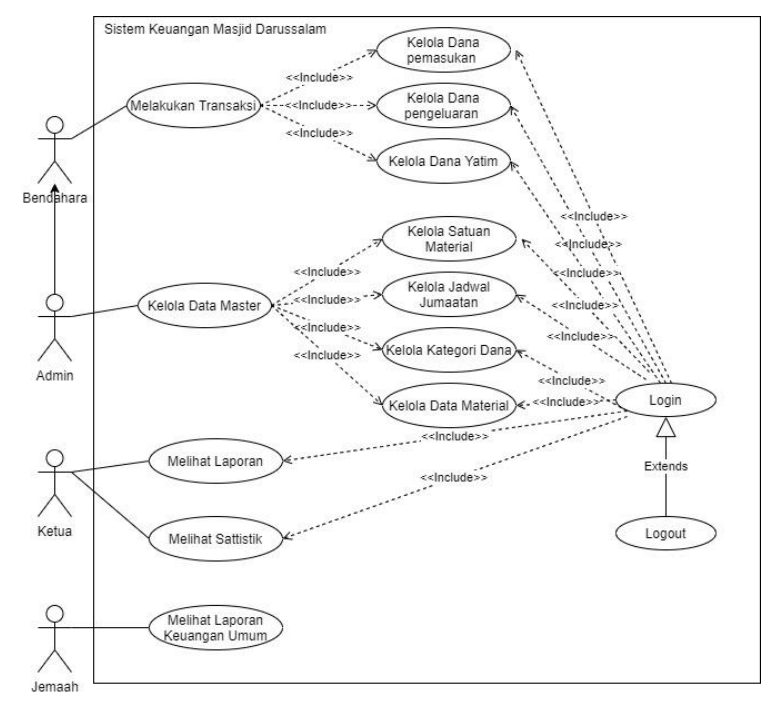

Gambar 1. Rancangan Usecase Sistem Pengelolaan Keuangan Masjid.

\section{Pengujian Sistem Pengelolaan Keuangan Masjid.}

Setelah dilakukan implementasi sistem pengelolaan keuangan masjid berbasis open source dengan platform android, selanjutnya dilakukan pengujian fitur sistem pengelolaan keuangan masjid berbasis open source dengan web dan platform android. Pada tahap ini dilakukan pengujian beta testing dan alpha testing (user) sistem pengelolaan keuangan masjid berbasis open source dengan platform android.

\section{HASIL DAN PEMBAHASAN}

Bagian berikut ini adalah hasil dari implementasi sistem pengelolaan keuangan masjid berbasis open source dengan web dan platform android.

\section{a. Analisis Hasil Implementasi Sistem Keuangan Masjid.}

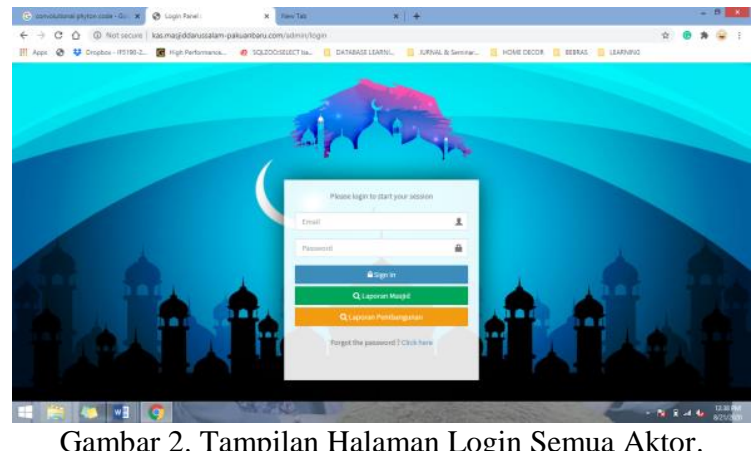

Gambar 2. Tampilan Halaman Login Semua Aktor

Pada bagian ini ditampilkan halaman login semua aktor pada sistem sistem pengelolaan keuangan masjid berbasis open source dengan web dan platform android. Pada halaman ini terdapat tiga jenis aktor yang dapat login, yakni admin, bendahara masjid dan ketua masjid. Untuk seluruh jamaah masjid, mereka dapat melihat laporan keuangan umum masjid secara umum tanpa melakukan login.

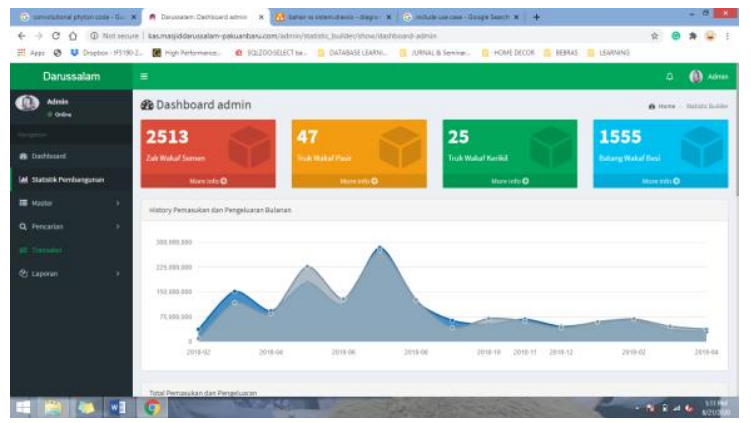

Gambar 3. Tampilan Infografis Data Keuangan Masjid.

Pada gambar 3 ditampilkan infografis data keuangan masjid. Bagian ini terdapat visualisasi grafik pemasukan dan pengeluaran dana Masjid pada sistem pengelolaan keuangan masjid berbasis open source dengan web dan platform android. 


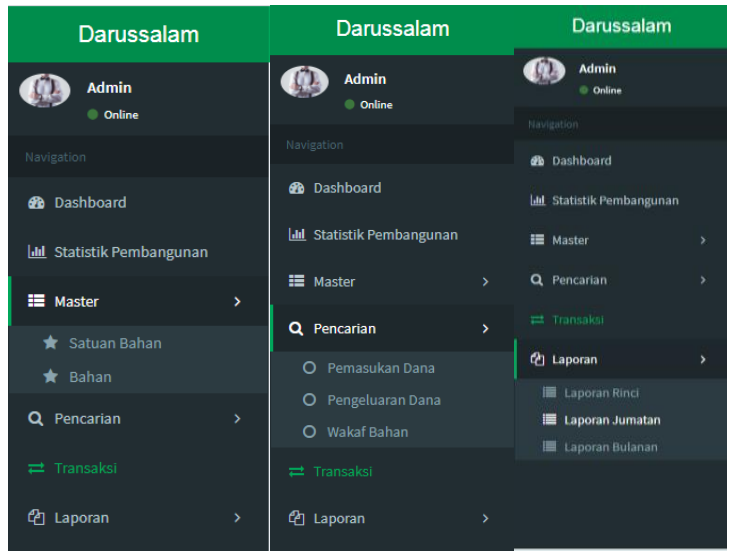

Gambar 4. Tampilan Submenu Halaman Admin.

Pada gambar 4 ditampilkan submenu pada halaman admin. Bagian ini terdapat daftar submenu apa saja yang terdapat dalam submenu pada halaman admin dalam sistem pengelolaan keuangan masjid berbasis open source dengan web dan platform android.

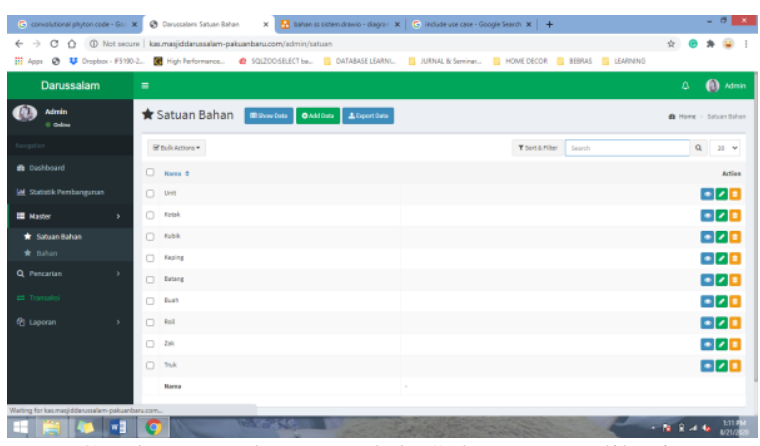

Gambar 5. Halaman Kelola Sub Menu Aplikasi.

Pada gambar 5 ditampilkan fitur pengelolaan submenu pada halaman admin. Bagian ini terdapat fitur pengelolaan seperti tambah data, ubah data, hapus data dan membuat field baru.

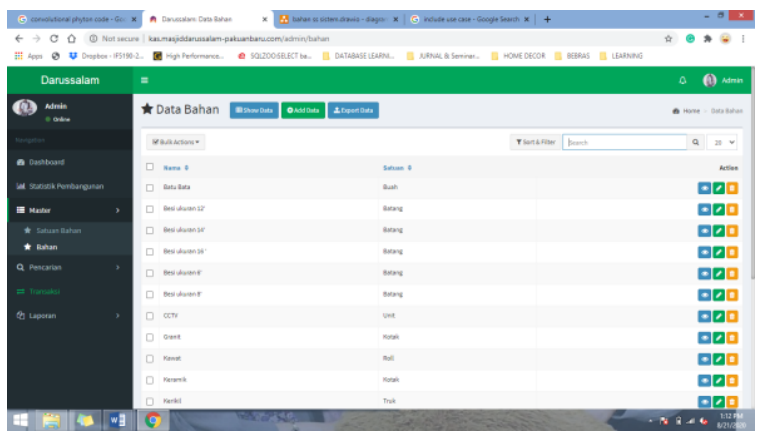

Gambar 6. Halaman Kelola Sub Menu Master.

Pada gambar 6 ditampilkan tampilan halaman kelola sub menu master. Pada sub menu Master ini, terdapat dua pengelolaan data yakni, satuan bahan dan jenis bahan. Bagian sub menu Master ini terdapat fitur pengelolaan seperti tambah data, ubah data, hapus data dan membuat field baru.

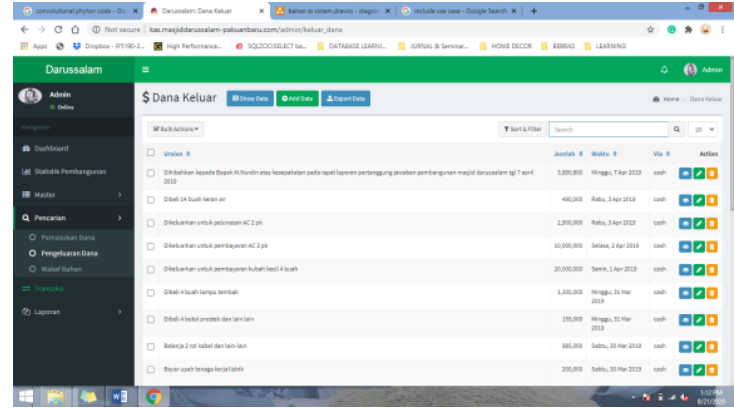

Gambar 7. Halaman Sub Menu Pengelolaan Dana.

Pada gambar 7 ditampilkan tampilan halaman kelola sub menu Pengelolaan Dana. Pada sub menu Pengeluaran Dana ini, terdapat tiga pengelolaan data yakni Pemasukan Dana, Pengeluaran dana dan Wakaf Bahan. Bagian sub menu Pengelolaan Dana ini terdapat fitur pengelolaan seperti tambah data, ubah data, hapus data dan membuat field baru.

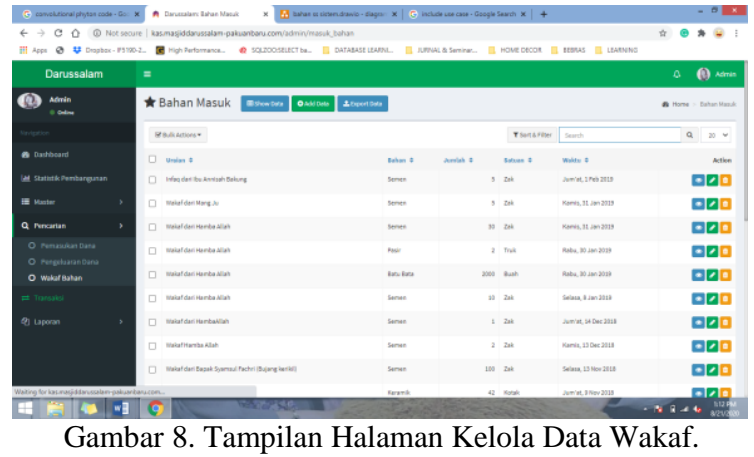

Pada gambar 8 ditampilkan tampilan halaman kelola sub menu Wakaf Bahan. Bagian sub menu Wakaf Bahan ini terdapat fitur pengelolaan seperti tambah data, ubah data, dan hapus data.

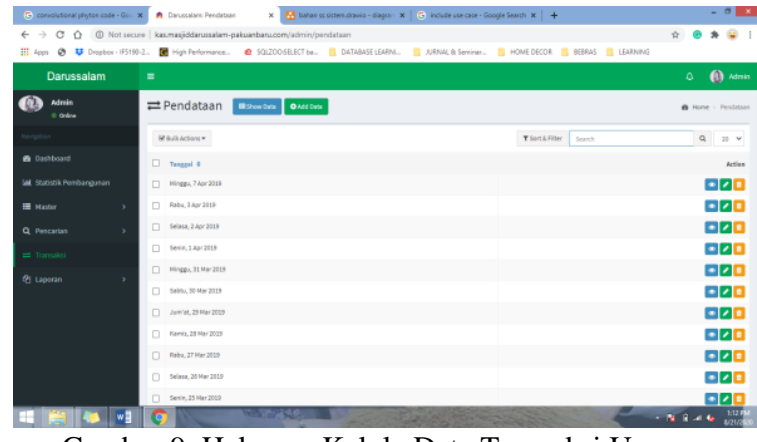

Gambar 9. Halaman Kelola Data Transaksi Umum.

Pada gambar 9 ditampilkan tampilan halaman kelola sub menu Transaksi Umum. Bagian sub menu Transaksi Umum ini terdapat fitur pengelolaan seperti tambah data, ubah data, dan hapus data. 


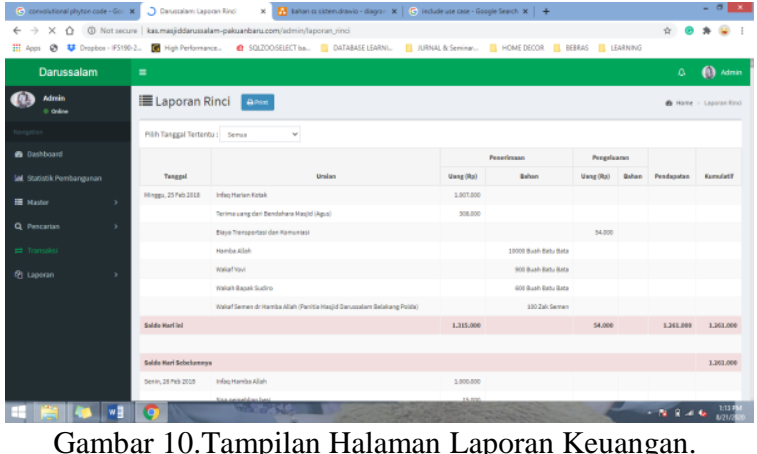

Pada gambar 10 ditampilkan tampilan halaman kelola sub menu master. Pada sub menu Master ini, terdapat dua pengelolaan data yakni, satuan bahan dan jenis bahan. Bagian sub menu Master ini terdapat fitur pengelolaan seperti tambah data, ubah data, hapus data dan membuat field baru.

\section{b. Analisis Hasil Pengujian Sistem Keuangan Masjid.}

Pada bagian ini, ditampilkan data-data hasil pengujian sistem pengelolaan keuangan masjid berbasis open source dengan web dan platform android.

Tabel 1. Daftar Umum Pengujian Blackbox.

\begin{tabular}{|c|c|c|c|c|}
\hline $\begin{array}{l}\mathbf{N} \\
\mathbf{0}\end{array}$ & $\begin{array}{c}\text { Nama } \\
\text { Kegiatan }\end{array}$ & $\begin{array}{l}\text { Testing } \\
\text { Button }\end{array}$ & Kode & Status \\
\hline \multirow[t]{4}{*}{1} & Melakukan & Mulai & $\mathrm{T} 1$ & Berhasil \\
\hline & Transaksi & Detail & $\mathrm{T} 2$ & Berhasil \\
\hline & & Level Button & T3 & Berhasil \\
\hline & & Berhenti & $\mathrm{T} 4$ & Berhasil \\
\hline \multirow[t]{6}{*}{2} & Kelola Dana & Tambah & M1 & Berhasil \\
\hline & Pemasukan & Edit & M2 & Berhasil \\
\hline & & Hapus & M3 & Berhasil \\
\hline & & Ubah & M4 & Berhasil \\
\hline & & Simpan & M5 & Berhasil \\
\hline & & Batal & M6 & Berhasil \\
\hline \multirow[t]{6}{*}{3} & Kelola Dana & Tambah & K1 & Berhasil \\
\hline & Pengeluaran & Edit & $\mathrm{K} 2$ & Berhasil \\
\hline & & Hapus & $\mathrm{K} 3$ & Berhasil \\
\hline & & Ubah & K4 & Berhasil \\
\hline & & Simpan & K5 & Berhasil \\
\hline & & Batal & K6 & Berhasil \\
\hline \multirow[t]{6}{*}{4} & Kelola Dana & Tambah & $\mathrm{Y} 1$ & Berhasil \\
\hline & Yatim & Edit & $\mathrm{Y} 2$ & Berhasil \\
\hline & & Hapus & Y3 & Berhasil \\
\hline & & Ubah & Y4 & Berhasil \\
\hline & & Simpan & Y5 & Berhasil \\
\hline & & Batal & Y6 & Berhasil \\
\hline \multirow[t]{4}{*}{5} & Kelola Data & Mulai & MA1 & Berhasil \\
\hline & Master & Detail & MA2 & Berhasil \\
\hline & & Level Button & MA3 & Berhasil \\
\hline & & Berhenti & MA4 & Berhasil \\
\hline \multirow[t]{6}{*}{6} & Kelola & Tambah & SM1 & Berhasil \\
\hline & Satuan & Edit & SM2 & Berhasil \\
\hline & Material & Hapus & SM3 & Berhasil \\
\hline & & Ubah & SM4 & Berhasil \\
\hline & & Simpan & SM5 & Berhasil \\
\hline & & Batal & SM6 & Berhasil \\
\hline \multirow[t]{6}{*}{7} & Kelola & Tambah & $\mathrm{J} 1$ & Berhasil \\
\hline & Jadwal & Edit & $\mathrm{J} 2$ & Berhasil \\
\hline & Jumaatan & Hapus & $\mathrm{J} 3$ & Berhasil \\
\hline & & Ubah & J4 & Berhasil \\
\hline & & Simpan & J5 & Berhasil \\
\hline & & Batal & J6 & Berhasil \\
\hline 8 & Kelola & Tambah & D1 & Berhasil \\
\hline
\end{tabular}

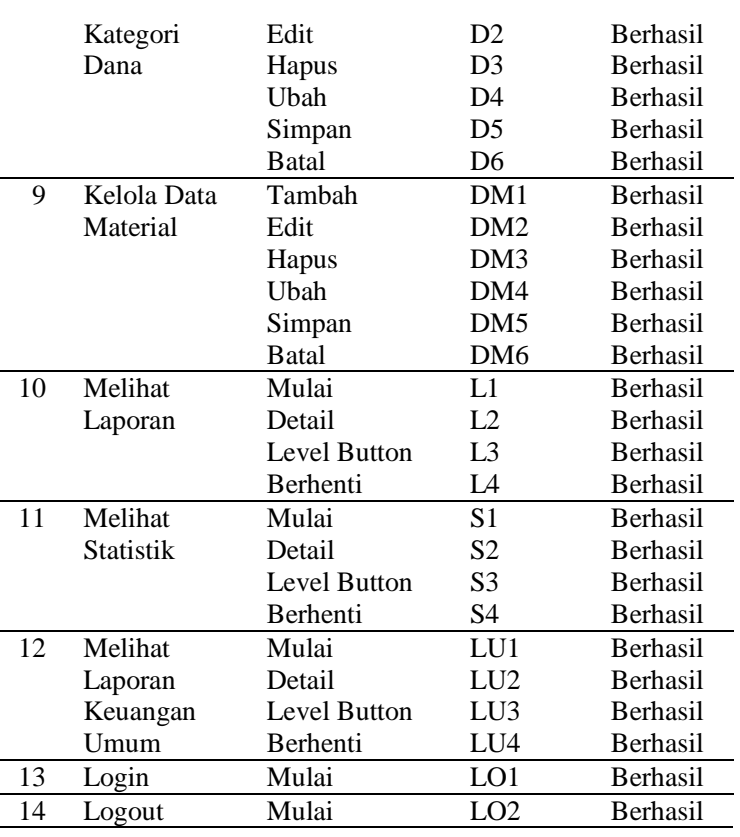

Tabel 1 di atas menampilkan hasil pengujian menu umum dengan metode Blackbox Testing. Terdapat 14 Menu yang merupakan interaksi antara aktor (admin, bendahara, ketua dan jamaah terhadap sistem pengelolaan keuangan masjid berbasis open source dengan web dan platform android. Dari hasil pengujian yang dilakukan dinyatakan bahwa semua menu berjalan baik dan sesuai dengan ekspektasi yang diharapkan.

Tabel 2. Detail Pengujian Blackbox Pada Menu Transaksi

\begin{tabular}{llllll}
\hline $\begin{array}{l}\text { Ko } \\
\text { de }\end{array}$ & $\begin{array}{l}\text { Aktiv } \\
\text { itas }\end{array}$ & $\begin{array}{l}\text { Ekspek } \\
\text { tasi }\end{array}$ & Realisasi & Hasil & $\begin{array}{l}\text { Kesim } \\
\text { pulan }\end{array}$ \\
\hline T1 & Klik & Menu & Menu & Menu & {$[\mathrm{x}]$} \\
& Trans & Transak & Transaksi & Transaks & Diterim \\
& aksi & si bisa & dapat & i terbuka & a [ ] \\
& & diklik & diklik & & Ditolak \\
\hline T2 & Klik & Menu & Menu & Menu & {$[\mathrm{x}]$} \\
& Detai & Detail & Detail & Detail & Diterim \\
& l & Transak & Transaksid & Transaks & a [ ] \\
& Trans & sibisa & apat & iterbuka & Ditolak \\
& aksi & diklik & Diklik & & \\
\hline T3 & Klik & Menu & Menu & Menu & {$[\mathrm{x}]$} \\
& Level & Level & Level & Level & Diterim \\
& Trans & Transak & Transaksid & Transaks & a [ ] \\
& aksi & sibisa & apat & iterbuka & Ditolak \\
& & diklik & Diklik & & \\
\hline T4 & Klik & Menu & Menu & Menu & {$[\mathrm{x}]$} \\
& Stop & Stop & Stop & Stop & Diterim \\
& Trans & Transak & Transaksid & Transaks & a [ ] \\
& aksi & sibisa & apat & iterbuka & Ditolak \\
& & diklik & Diklik & & \\
\hline & & & & & \\
\hline
\end{tabular}

Pada tabel 2 di atas merupakan detail hasil pengujian dari menu Dana Keluar. Terdapat empat aktivitas yang diuji antara lain klik transaksi, klik detail transaksi, klik level transaksi dan klik stop transaksi.

Dari hasil pengujian, harapan dan hasil yang diharapkan sudah sesuai. 
Tabel 3. Detail Pengujian Blackbox Pada Menu Dana

\begin{tabular}{|c|c|c|c|c|c|}
\hline \multicolumn{6}{|c|}{ Pemasukan. } \\
\hline $\begin{array}{l}\text { Ko } \\
\text { de }\end{array}$ & $\begin{array}{l}\text { Aktivi } \\
\text { tas }\end{array}$ & $\begin{array}{l}\text { Ekspek } \\
\text { tasi }\end{array}$ & $\begin{array}{l}\text { Realisas } \\
\text { i }\end{array}$ & Hasil & $\begin{array}{l}\text { Kesimpu } \\
\text { lan }\end{array}$ \\
\hline M1 & $\begin{array}{l}\text { Klik } \\
\text { Tamba } \\
\text { h Dana } \\
\text { Masuk }\end{array}$ & $\begin{array}{l}\text { Menu } \\
\text { Tambah } \\
\text { Dana } \\
\text { Masukb } \\
\text { isa } \\
\text { diklik }\end{array}$ & $\begin{array}{l}\text { Menu } \\
\text { Tambah } \\
\text { Dana } \\
\text { Masukd } \\
\text { apat } \\
\text { Diklik }\end{array}$ & $\begin{array}{l}\text { Menu } \\
\text { Tambah } \\
\text { Dana } \\
\text { Masukter } \\
\text { buka }\end{array}$ & $\begin{array}{l}{[\mathrm{x}]} \\
\text { Diterima } \\
{[\mathrm{]}} \\
\text { Ditolak }\end{array}$ \\
\hline M2 & $\begin{array}{l}\text { Klik } \\
\text { Edit } \\
\text { Dana } \\
\text { Masuk }\end{array}$ & $\begin{array}{l}\text { Menu } \\
\text { Edit } \\
\text { Dana } \\
\text { Masukb } \\
\text { isa } \\
\text { diklik } \\
\end{array}$ & $\begin{array}{l}\text { Menu } \\
\text { Edit } \\
\text { Dana } \\
\text { Masukd } \\
\text { apat } \\
\text { Diklik } \\
\end{array}$ & $\begin{array}{l}\text { Menu Edit } \\
\text { Dana } \\
\text { Masukter } \\
\text { buka }\end{array}$ & $\begin{array}{l}\mathrm{x}] \\
\text { Diterima } \\
{[]} \\
\text { Ditolak }\end{array}$ \\
\hline M3 & $\begin{array}{l}\text { Klik } \\
\text { Hapus } \\
\text { Dana } \\
\text { Masuk }\end{array}$ & $\begin{array}{l}\text { Menu } \\
\text { Hapus } \\
\text { Dana } \\
\text { Masukb } \\
\text { isa } \\
\text { diklik } \\
\end{array}$ & $\begin{array}{l}\text { Menu } \\
\text { Hapus } \\
\text { Dana } \\
\text { Masukd } \\
\text { apat } \\
\text { Diklik } \\
\end{array}$ & $\begin{array}{l}\text { Menu } \\
\text { Hapus } \\
\text { Dana } \\
\text { Masukter } \\
\text { buka }\end{array}$ & $\begin{array}{l}{[\mathrm{x}]} \\
\text { Diterima } \\
{[\mathrm{]}} \\
\text { Ditolak }\end{array}$ \\
\hline M4 & $\begin{array}{l}\text { Klik } \\
\text { Ubah } \\
\text { Dana } \\
\text { Masuk }\end{array}$ & $\begin{array}{l}\text { Menu } \\
\text { Ubah } \\
\text { Dana } \\
\text { Masukb } \\
\text { isa } \\
\text { diklik } \\
\end{array}$ & $\begin{array}{l}\text { Menu } \\
\text { Ubah } \\
\text { Dana } \\
\text { Masukd } \\
\text { apat } \\
\text { Diklik } \\
\end{array}$ & $\begin{array}{l}\text { Menu } \\
\text { Ubah } \\
\text { Dana } \\
\text { Masukter } \\
\text { buka }\end{array}$ & $\begin{array}{l}\mathrm{x}] \\
\text { Diterima } \\
{[\mathrm{]}} \\
\text { Ditolak }\end{array}$ \\
\hline M5 & $\begin{array}{l}\text { Klik } \\
\text { Simpa } \\
\text { n Dana } \\
\text { Masuk }\end{array}$ & $\begin{array}{l}\text { Menu } \\
\text { Simpan } \\
\text { Dana } \\
\text { Masukb } \\
\text { isa } \\
\text { diklik }\end{array}$ & $\begin{array}{l}\text { Menu } \\
\text { Simpan } \\
\text { Dana } \\
\text { Masukd } \\
\text { apat } \\
\text { Diklik }\end{array}$ & $\begin{array}{l}\text { Menu } \\
\text { Simpan } \\
\text { Dana } \\
\text { Masukter } \\
\text { buka }\end{array}$ & $\begin{array}{l}{[\mathrm{x}]} \\
\text { Diterima } \\
{[]} \\
\text { Ditolak }\end{array}$ \\
\hline M6 & $\begin{array}{l}\text { Klik } \\
\text { Batal } \\
\text { Dana } \\
\text { Masuk }\end{array}$ & $\begin{array}{l}\text { Menu } \\
\text { Batal } \\
\text { Dana } \\
\text { Masukb } \\
\text { isa } \\
\text { diklik }\end{array}$ & $\begin{array}{l}\text { Menu } \\
\text { Batal } \\
\text { Dana } \\
\text { Masukd } \\
\text { apat } \\
\text { Diklik }\end{array}$ & $\begin{array}{l}\text { Menu } \\
\text { Batal } \\
\text { Dana } \\
\text { Masukter } \\
\text { buka }\end{array}$ & $\begin{array}{l}{[\mathrm{x}]} \\
\text { Diterima } \\
{[\mathrm{]}} \\
\text { Ditolak }\end{array}$ \\
\hline
\end{tabular}

Pada tabel 3 di atas merupakan detail hasil pengujian dari menu Dana Masuk. Terdapat enam aktivitas yang diuji antara lain klik tambah dana masuk, klik edit dana masuk, klik hapus dana masuk, klik ubah dana masuk, klik simpan dana masuk dan klik batal dana masuk, Dari hasil pengujian, harapan dan hasil yang diharapkan sudah sesuai.

Tabel 4. Detail Pengujian Blackbox Pada Menu Dana Pengeluaran.

\begin{tabular}{|c|c|c|c|c|c|}
\hline $\begin{array}{l}\text { Ko } \\
\text { de }\end{array}$ & $\begin{array}{c}\text { Aktivi } \\
\text { tas }\end{array}$ & $\begin{array}{c}\text { Ekspek } \\
\text { tasi }\end{array}$ & $\begin{array}{c}\text { Realisa } \\
\text { si }\end{array}$ & Hasil & $\begin{array}{c}\text { Kesimp } \\
\text { ulan }\end{array}$ \\
\hline K1 & $\begin{array}{l}\text { Klik } \\
\text { Tamba } \\
\text { h } \\
\text { Dana } \\
\text { Keluar }\end{array}$ & $\begin{array}{l}\text { Menu } \\
\text { Tamba } \\
\text { h Dana } \\
\text { Keluar } \\
\text { bisa } \\
\text { diklik }\end{array}$ & $\begin{array}{l}\text { Menu } \\
\text { Tambah } \\
\text { Dana } \\
\text { Keluard } \\
\text { apat } \\
\text { Diklik }\end{array}$ & $\begin{array}{l}\text { Menu } \\
\text { Tambah } \\
\text { Dana } \\
\text { Keluarter } \\
\text { buka }\end{array}$ & $\begin{array}{l}{[\mathrm{x}]} \\
\text { Diterima } \\
{[]} \\
\text { Ditolak }\end{array}$ \\
\hline $\mathrm{K} 2$ & $\begin{array}{l}\text { Klik } \\
\text { Edit } \\
\text { Dana } \\
\text { Keluar }\end{array}$ & $\begin{array}{l}\text { Menu } \\
\text { Edit } \\
\text { Dana } \\
\text { Keluar } \\
\text { bisa } \\
\text { diklik }\end{array}$ & $\begin{array}{l}\text { Menu } \\
\text { Edit } \\
\text { Dana } \\
\text { Keluard } \\
\text { apat } \\
\text { Diklik }\end{array}$ & $\begin{array}{l}\text { Menu } \\
\text { Edit } \\
\text { Dana } \\
\text { Keluarter } \\
\text { buka }\end{array}$ & $\begin{array}{l}{[\mathrm{x}]} \\
\text { Diterima } \\
{[]} \\
\text { Ditolak }\end{array}$ \\
\hline K3 & $\begin{array}{l}\text { Klik } \\
\text { Hapus } \\
\text { Dana } \\
\text { Keluar }\end{array}$ & $\begin{array}{l}\text { Menu } \\
\text { Hapus } \\
\text { Dana } \\
\text { Keluarb } \\
\text { isa } \\
\text { diklik }\end{array}$ & $\begin{array}{l}\text { Menu } \\
\text { Hapus } \\
\text { Dana } \\
\text { Keluard } \\
\text { apat } \\
\text { Diklik }\end{array}$ & $\begin{array}{l}\text { Menu } \\
\text { Hapus } \\
\text { Dana } \\
\text { Keluarter } \\
\text { buka }\end{array}$ & $\begin{array}{l}{[\mathrm{x}]} \\
\text { Diterima } \\
{[]} \\
\text { Ditolak }\end{array}$ \\
\hline
\end{tabular}

\begin{tabular}{llllll}
\hline K4 & Klik & Menu & Menu & Menu & {$[\mathrm{x}]$} \\
& Ubah & Ubah & Ubah & Ubah & Diterima \\
& Dana & Dana & Dana & Dana & {[]} \\
& Keluar & Keluarb & Keluard & Keluarter & Ditolak \\
& & $\begin{array}{l}\text { isa } \\
\text { diklik }\end{array}$ & $\begin{array}{l}\text { apat } \\
\text { biklik }\end{array}$ & & \\
& & Menu & Menu & Menu & {$[\mathrm{x}]$} \\
\hline K5 & Klik & Menu & Simpan & Simpan & Diterima \\
& Simpa & Simpan & Sima & [ ] \\
& n & Dana & Dana & Dana & Kitolak \\
& Dana & Keluarb & Keluard & Keluarter & Dita \\
& Keluar & isa & apat & buka & \\
& & diklik & Diklik & & \\
\hline K6 & Klik & Menu & Menu & Menu & {$[\mathrm{x}]$} \\
& Batal & Batal & Batal & Batal & Diterima \\
& Dana & Dana & Dana & Dana & {[]} \\
& Keluar & Keluarb & Keluard & Keluarter & Ditolak \\
& & isa & apat & buka & \\
& & diklik & Diklik & & \\
\hline
\end{tabular}

Pada tabel 4 di atas merupakan detail hasil pengujian dari menu Dana Keluar. Terdapat enam aktivitas yang diuji antara lain klik tambah dana keluar, klik edit dana keluar, klik hapus dana keluar, klik ubah dana keluar, klik simpan dana keluar dan klik batal dana keluar, Dari hasil pengujian, harapan dan hasil yang diharapkan sudah sesuai.

Tabel 5. Detail Pengujian Blackbox Pada Menu Dana

\begin{tabular}{|c|c|c|c|c|c|}
\hline $\begin{array}{l}\text { Ko } \\
\text { de }\end{array}$ & $\begin{array}{l}\text { Aktivi } \\
\text { tas }\end{array}$ & $\begin{array}{l}\text { Ekspekt } \\
\text { asi }\end{array}$ & $\begin{array}{l}\text { Realisas } \\
\text { i }\end{array}$ & Hasil & $\begin{array}{l}\text { Kesimpu } \\
\text { lan }\end{array}$ \\
\hline $\mathrm{Y} 1$ & $\begin{array}{l}\text { Klik } \\
\text { Tamba } \\
\text { h Dana } \\
\text { Yatim }\end{array}$ & $\begin{array}{l}\text { Menu } \\
\text { Tambah } \\
\text { Dana } \\
\text { Yatimbi } \\
\text { sa diklik }\end{array}$ & $\begin{array}{l}\text { Menu } \\
\text { Tambah } \\
\text { Dana } \\
\text { Yatimda } \\
\text { pat } \\
\text { Diklik }\end{array}$ & $\begin{array}{l}\text { Menu } \\
\text { Tambah } \\
\text { Dana } \\
\text { Yatimterb } \\
\text { uka }\end{array}$ & $\begin{array}{l}{[\mathrm{x}]} \\
\text { Diterima } \\
{[]} \\
\text { Ditolak }\end{array}$ \\
\hline $\mathrm{Y} 2$ & $\begin{array}{l}\text { Klik } \\
\text { Edit } \\
\text { Dana } \\
\text { Yatim }\end{array}$ & $\begin{array}{l}\text { Menu } \\
\text { Edit } \\
\text { Dana } \\
\text { Yatimbi } \\
\text { sa diklik }\end{array}$ & $\begin{array}{l}\text { Menu } \\
\text { Edit } \\
\text { Dana } \\
\text { Yatimda } \\
\text { pat } \\
\text { Diklik } \\
\end{array}$ & $\begin{array}{l}\text { Menu } \\
\text { Edit Dana } \\
\text { Yatimterb } \\
\text { uka }\end{array}$ & $\begin{array}{l}{[\mathrm{x}]} \\
\text { Diterima } \\
{[]} \\
\text { Ditolak }\end{array}$ \\
\hline Y3 & $\begin{array}{l}\text { Klik } \\
\text { Hapus } \\
\text { Dana } \\
\text { Yatim }\end{array}$ & $\begin{array}{l}\text { Menu } \\
\text { Hapus } \\
\text { Dana } \\
\text { Yatimbi } \\
\text { sa diklik }\end{array}$ & $\begin{array}{l}\text { Menu } \\
\text { Hapus } \\
\text { Dana } \\
\text { Yatimda } \\
\text { pat } \\
\text { Diklik } \\
\end{array}$ & $\begin{array}{l}\text { Menu } \\
\text { Hapus } \\
\text { Dana } \\
\text { Yatimterb } \\
\text { uka }\end{array}$ & $\begin{array}{l}\mathrm{x}] \\
\text { Diterima } \\
{[]} \\
\text { Ditolak }\end{array}$ \\
\hline Y4 & $\begin{array}{l}\text { Klik } \\
\text { Ubah } \\
\text { Dana } \\
\text { Yatim }\end{array}$ & $\begin{array}{l}\text { Menu } \\
\text { Ubah } \\
\text { Dana } \\
\text { Yatimbi } \\
\text { sa diklik }\end{array}$ & $\begin{array}{l}\text { Menu } \\
\text { Ubah } \\
\text { Dana } \\
\text { Yatimda } \\
\text { pat } \\
\text { Diklik } \\
\end{array}$ & $\begin{array}{l}\text { Menu } \\
\text { Ubah } \\
\text { Dana } \\
\text { Yatimterb } \\
\text { uka }\end{array}$ & $\begin{array}{l}{[\mathrm{x}]} \\
\text { Diterima } \\
{[]} \\
\text { Ditolak }\end{array}$ \\
\hline Y5 & $\begin{array}{l}\text { Klik } \\
\text { Simpa } \\
\text { n Dana } \\
\text { Yatim }\end{array}$ & $\begin{array}{l}\text { Menu } \\
\text { Simpan } \\
\text { Dana } \\
\text { Yatimbi } \\
\text { sa diklik }\end{array}$ & $\begin{array}{l}\text { Menu } \\
\text { Simpan } \\
\text { Dana } \\
\text { Yatimda } \\
\text { pat } \\
\text { Diklik }\end{array}$ & $\begin{array}{l}\text { Menu } \\
\text { Simpan } \\
\text { Dana } \\
\text { Yatimterb } \\
\text { uka }\end{array}$ & $\begin{array}{l}{[\mathrm{x}]} \\
\text { Diterima } \\
{[\text { ] }} \\
\text { Ditolak }\end{array}$ \\
\hline Y6 & $\begin{array}{l}\text { Klik } \\
\text { Batal } \\
\text { Dana } \\
\text { Yatim }\end{array}$ & $\begin{array}{l}\text { Menu } \\
\text { Batal } \\
\text { Dana } \\
\text { Yatimbi } \\
\text { sa diklik }\end{array}$ & $\begin{array}{l}\text { Menu } \\
\text { Batal } \\
\text { Dana } \\
\text { Yatimda } \\
\text { pat } \\
\text { Diklik }\end{array}$ & $\begin{array}{l}\text { Menu } \\
\text { Batal } \\
\text { Dana } \\
\text { Yatimterb } \\
\text { uka }\end{array}$ & $\begin{array}{l}{[\mathrm{x}]} \\
\text { Diterima } \\
{[]} \\
\text { Ditolak }\end{array}$ \\
\hline
\end{tabular}

Pada tabel 5 di atas merupakan detail hasil pengujian dari menu Dana Yatim. Terdapat enam aktivitas yang diuji antara lain klik tambah dana yatim, klik 
edit dana yatim, klik hapus dana yatim, klik ubah dana yatim, klik simpan dana yatim dan klik batal dana yatim, Dari hasil pengujian, harapan dan hasil yang diharapkan sudah sesuai.

Tabel 6. Detail Pengujian Blackbox Pada Menu Transaksi Umum.

\begin{tabular}{|c|c|}
\hline Kode Tester & Desripsi Tester \\
\hline T1 & Tester (Bendahara) \\
\hline T2 & Tester (Ketua) \\
\hline T3 & Tester (Admin) \\
\hline T4 & Tester (Pengurus 1) \\
\hline T5 & Tester (Pengurus 2) \\
\hline T6 & Tester (Pengurus 1) \\
\hline T7 & Tester (Jamaah) \\
\hline
\end{tabular}

Pada tabel 6 di atas ditampilkan detail pengujian blackbox pada menu transaksi pada aplikasi keuangan masjid. Kami Mengujikan aplikasi ini pada level user atau pengujian alpha. Terdapat tujuh penguji sistema yang merupakan orang-orang yang berperan aktif dalam sistema pengelolaan masjid.

Tabel 7. Pengujian User Aplikasi Keuangan Masjid.

\begin{tabular}{|l|l|l|l|l|l|l|l|}
\hline Kode & T1 & T2 & T3 & T4 & T5 & T7 & Rerata \\
\hline T1 & 74 & 82 & 76 & 79 & 81 & 94 & 81.00 \\
\hline T2 & 80 & 95 & 86 & 75 & 88 & 94 & 86.33 \\
\hline T3 & 89 & 94 & 72 & 82 & 75 & 85 & 82.83 \\
\hline T4 & 87 & 91 & 95 & 86 & 87 & 81 & 87.83 \\
\hline M1 & 76 & 93 & 89 & 74 & 83 & 93 & 84.67 \\
\hline M2 & 79 & 90 & 84 & 73 & 84 & 94 & 84.00 \\
\hline M3 & 90 & 87 & 85 & 95 & 75 & 72 & 84.00 \\
\hline M4 & 93 & 90 & 90 & 71 & 74 & 87 & 84.17 \\
\hline M5 & 93 & 92 & 79 & 74 & 82 & 77 & 82.83 \\
\hline M6 & 82 & 79 & 75 & 84 & 75 & 75 & 78.33 \\
\hline K1 & 94 & 71 & 86 & 76 & 84 & 92 & 83.83 \\
\hline K2 & 77 & 94 & 93 & 71 & 71 & 88 & 82.33 \\
\hline K3 & 85 & 93 & 80 & 83 & 74 & 92 & 84.50 \\
\hline K4 & 93 & 87 & 86 & 76 & 76 & 91 & 84.83 \\
\hline K5 & 86 & 80 & 92 & 90 & 75 & 92 & 85.83 \\
\hline K6 & 79 & 70 & 95 & 80 & 82 & 89 & 82.50 \\
\hline Y1 & 74 & 76 & 81 & 94 & 79 & 80 & 80.67 \\
\hline Y2 & 93 & 92 & 73 & 76 & 82 & 81 & 82.83 \\
\hline Y3 & 92 & 75 & 77 & 95 & 88 & 89 & 86.00 \\
\hline Y4 & 95 & 81 & 76 & 71 & 82 & 77 & 80.33 \\
\hline Y5 & 73 & 73 & 86 & 91 & 87 & 93 & 83.83 \\
\hline Y6 & 84 & 95 & 90 & 82 & 92 & 77 & 86.67 \\
\hline MA1 & 71 & 83 & 85 & 75 & 84 & 85 & 80.50 \\
\hline MA2 & 91 & 93 & 87 & 91 & 71 & 75 & 84.67 \\
\hline MA3 & 71 & 90 & 71 & 84 & 83 & 86 & 80.83 \\
\hline MA4 & 76 & 85 & 75 & 70 & 88 & 92 & 81.00 \\
\hline SM1 & 94 & 90 & 84 & 83 & 89 & 85 & 87.50 \\
\hline SM2 & 88 & 73 & 84 & 81 & 73 & 92 & 81.83 \\
\hline SM3 & 92 & 92 & 94 & 74 & 91 & 80 & 87.17 \\
\hline SM4 & 82 & 72 & 85 & 93 & 89 & 71 & 82.00 \\
\hline SM5 & 73 & 93 & 83 & 92 & 89 & 71 & 83.50 \\
\hline SM6 & 93 & 94 & 71 & 73 & 76 & 90 & 82.83 \\
\hline J1 & 77 & 80 & 81 & 79 & 72 & 79 & 78.00 \\
\hline J2 & 84 & 79 & 73 & 71 & 75 & 91 & 78.83 \\
\hline J3 & 91 & 95 & 90 & 90 & 87 & 90 & 90.50 \\
\hline J4 & 90 & 90 & 70 & 81 & 88 & 88 & 84.50 \\
\hline J5 & 70 & 80 & 95 & 82 & 79 & 91 & 82.83 \\
\hline J6 & 93 & 93 & 70 & 75 & 77 & 95 & 83.83 \\
\hline D1 & 77 & 90 & 84 & 81 & 70 & 93 & 82.50 \\
\hline D2 & 85 & 89 & 80 & 72 & 70 & 89 & 80.83 \\
\hline D3 & 72 & 82 & 78 & 90 & 79 & 76 & 79.50 \\
\hline D4 & 84 & 73 & 92 & 89 & 87 & 85 & 85.00 \\
\hline & & & & & & \\
\hline
\end{tabular}

\begin{tabular}{|l|l|l|l|l|l|l|l|} 
D5 & 88 & 72 & 71 & 72 & 77 & 89 & 78.17 \\
\hline D6 & 83 & 92 & 78 & 89 & 76 & 92 & 85.00 \\
\hline DM1 & 93 & 95 & 95 & 75 & 88 & 86 & 88.67 \\
\hline DM2 & 79 & 80 & 94 & 90 & 73 & 75 & 81.83 \\
\hline DM3 & 75 & 72 & 84 & 94 & 75 & 72 & 78.67 \\
\hline DM4 & 75 & 93 & 78 & 74 & 86 & 91 & 82.83 \\
\hline DM5 & 75 & 94 & 78 & 78 & 88 & 74 & 81.17 \\
\hline DM6 & 77 & 93 & 80 & 76 & 85 & 77 & 81.33 \\
\hline L1 & 92 & 88 & 87 & 71 & 74 & 86 & 83.00 \\
\hline L2 & 70 & 81 & 70 & 95 & 85 & 95 & 82.67 \\
\hline L3 & 94 & 91 & 73 & 93 & 70 & 80 & 83.50 \\
\hline L4 & 71 & 70 & 70 & 76 & 71 & 81 & 73.17 \\
\hline S1 & 83 & 83 & 74 & 72 & 73 & 94 & 79.83 \\
\hline S2 & 92 & 73 & 81 & 93 & 93 & 80 & 85.33 \\
\hline S3 & 91 & 81 & 80 & 93 & 93 & 85 & 87.17 \\
\hline S4 & 93 & 89 & 85 & 75 & 94 & 95 & 88.50 \\
\hline LU1 & 81 & 85 & 75 & 79 & 78 & 82 & 80.00 \\
\hline LU2 & 73 & 90 & 83 & 90 & 74 & 81 & 81.83 \\
\hline LU3 & 82 & 75 & 71 & 86 & 95 & 82 & 81.83 \\
\hline LU4 & 86 & 95 & 83 & 78 & 84 & 75 & 83.50 \\
\hline LO1 & 91 & 93 & 81 & 85 & 71 & 70 & 81.83 \\
\hline LO2 & 76 & 77 & 93 & 76 & 74 & 95 & 81.83 \\
\hline
\end{tabular}

Pada tabel 7 di atas ditampilkan hasil pengujian user pada aplikasi keuangan masjid yang kami riset. Terdapat 14 aktivitas utama dan 70 aktivitas tambahan yang harus di uji oleh seluruh user dalam kegiatan testing ini.

Setiap aktivitas yang diuji, kami berikan nilai rentang 0-100. Kolom rerata menunjukan nilai hasil dari penilaian seluruh user yang menunjukan penilaian terhadap sistema pengelolaan keuangan masjid yang kami bangun sesuai proses bisnis pada Masjid Darussalam Pakuan Baru di Kota Jambi.

\section{\% Rerata Alpha Testing}

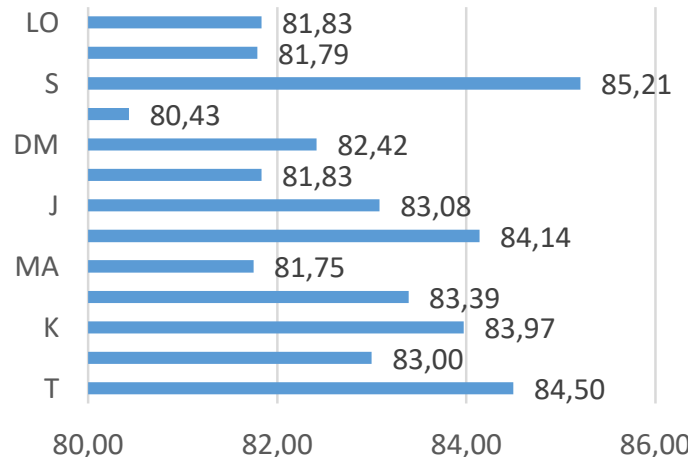

Gambar 11.Visualisasi Hasil Pengujian pada Level User

Gambar 11 adalah grafik yang menampilkan penilaian yang dihasilkan oleh kegiatan alpha testing yang dilakukan terhadap Aplikasi Pengelolaan Keuangan Masjid berbasis Web dan Android. Dari hasil penilaian yang dilakukan ratarata user menilai aplikasi dengan nilai sangat baik.

\section{KESIMPULAN}

Pengelolaan keuangan masjid merupakan suatu 
kegiatan yang harus dimanajemen dengan hatihati dan baik. Penerapan aplikasi dengan seluruh rangkaian Software Engineering yang baik harus dilakukan dengan tetap sesuai dengan proses bisnis yang berlaku dan tidak merubah arus data dan laporan yang sudah berjalan bertahun-tahun sebelumnya. Penerapan aplikasi berbasis Website dan Platform Android yang kami lakukan, mampu menghasilkan manajemen keuangan masjid yang otomatis dan terkomputerisasi dan dinilai sangat baik pada pengujian user.

\section{REFERENSI}

Alamsyah, M. R., Rahayu, S., \& Muslih, M. (2017). Kompetensi Sumber Daya Manusia, Penerapan Sistem Akuntansi Keuangan Daerah (Sakd), Pemanfaatan Teknologi Informasi, Dan Sistem Pengendalian Internal Terhadap Kualitas Laporan Keuangan Daerah (Studi Empiris Pada Satuan Kineja Perangkat Daerah (Skpd) Kota D. Majalah Ilmiah UNIKOM. https://doi.org/10.34010/miu.v15i2.559

Dennis, A., \& Haley, W. B. (2010). System Analysis and Design with UML 2.0. Wiley. https://doi.org/10.18653/v1/D15-1049

Diani, D. I. (2014). PENGARUH PEMAHAMAN AKUNTANSI, PEMANFAATAN SISTEM INFORMASI AKUNTANSI KEUANGAN DAERAH DAN PERAN INTERNAL AUDIT TERHADAP KUALITAS LAPORAN KEUANGAN PEMERINTAH DAERAH (Studi Empiris pada Satuan Kerja Perangkat Daerah di Kota Pariaman). Skripsi Universitas Negeri Medan.

Enck, W., Octeau, D., \& Mcdaniel, P. (2011). A Study of Android Application Security.

Fachruddin, F., \& Pratama, Y. (2017). Eksperimen Seleksi Fitur Pada Parameter Proyek Untuk Software Effort Estimation dengan K-Nearest Neighbor. JURNAL INFORMATIKA : Jurnal Pengembangan IT, 2(2), 53-62. Retrieved from

http://ejournal.poltektegal.ac.id/index.php/info rmatika/article/view/510

Juwita, R. (2013). Pengaruh Implementasi Standar Akuntansi Pemerintahan dan Sistem Informasi Akuntansi Terhadap Kualitas Laporan Keuangan. Trikonomika, 12(2), 201. https://doi.org/10.23969/trikonomika.v12i2.48 0

Nugraha, H. A., \& Astuti, Y. W. (2013). Analisis Penerapan Sistem Informasi Manajemen Keuangan Daerah ( SIMDA Keuangan ) dalam Pengolahan Data Keuangan Pada Organisasi Pemerintah Daerah ( Studi Kasus Pada Dinas Kesehatan Kabupaten Nganjuk). Jurnal Akuntansi Aktual, 2(1), 25-33.

Popli, R. (2014). Cost and Effort Estimation in Agile Software Development. In International Conference on Reliability, Optimization and Information Technology (pp. 57-61).

Rusmayanti, A. (2015). Sistem Informasi Pengelolaan Keuangan Pada Desa Ngadirejan. Journal Speed - Sentra Penelitian Engineering Dan Edukasi, 12(1), 35-39.

\section{PROFIL PENULIS}

Fachruddin merupakan dosen yang aktif mengajar dan penelitian serta pengabdian di Universitas Dinamika Bangsa (UNAMA) Jambi. Bidang penelitian yang didalami antara lain adalah Pengolahan Citra. Saat ini sedang menjalani pendidikan S3 di Universitas Sriwijaya Palembang.

M. Riza Pahlevi merupakan dosen yang aktif mengajar dan penelitian serta pengabdian di Universitas Dinamika Bangsa (UNAMA) Jambi. Bidang penelitian yang didalami antara lain adalah sistem informasi. Menamatkan pendidikan S2 di Universitas Dinamika Bangsa Jambi pada juruan Magister Sistem Informasi.

Muhammad Ismail merupakan dosen yang aktif mengajar dan penelitian serta pengabdian di Universitas Dinamika Bangsa (UNAMA) Jambi. Bidang penelitian yang didalami antara lain adalah sistem informasi. Menamatkan pendidikan S1 \& S2 di Universitas Binus.

Errissya Rasywir merupakan dosen yang aktif mengajar dan penelitian serta pengabdian di Universitas Dinamika Bangsa (UNAMA) Jambi. Bidang penelitian yang didalami antara lain adalah kecerdasan buatan, pengolahan citra serta pengolahan teks. Menamatkan pendidikan S1 di Universitas Sriwijaya dan pendidikan S2 di Institut Teknologi Bandung. Selain itu, saat ini, juga menjabat Ketua Lembaga Penjaminan Mutu Pendidikan (LPMP) di UNAMA. 